\title{
Sedimentation Processes at the Navigation Channel of the Liquefied Natural Gas (LNG) Port, Nile Delta, Egypt
}

\author{
Essam Abd El-Halim Mohamed Deabes \\ Physical Oceanography Department, Coastal Research Institute (CoRI), Alexandria, Egypt \\ E-mail:Deabes@yahoo.com \\ Received March 12, 2010; revised April 11, 2010; accepted May 5, 2010
}

\begin{abstract}
Liquefied Natural Gas (LNG) port is located at Abu Qir Bay on the northwestern coast of the Nile delta, Egypt. The port was constructed in 2004 to export liquefied natural gas worldwide. The offshore basins of this port including the turning and berthing areas (15-m depth) are connected to the deep water by a $15-\mathrm{m}$ depth dredged channel that extends $4 \mathrm{~km}$ offshore. However, the navigation channel and its contiguous basins have experienced problematic shoaling that might affect the navigation activities of gas tankers. Sedimentation processes have been investigated by analyses of waves, currents, bathymetry, grain size of seabed and channel dimensions. Sedimentation rates are estimated using a developed numerical model. Sedimentation rate fluctuates between $0.048 \times 10^{6} \mathrm{~m}^{3} /$ month and $0.388 \times 10^{6} \mathrm{~m}^{3} /$ month, with an annual sedimentation rate of $1.977 \times 10^{6} \mathrm{~m}^{3} / \mathrm{yr}$. The variance in the sedimentation rates between winter and summer resulted in increasing of current speed and direction flowing towards offshore. The sedimentation process is influenced by the temporal variability in the direction and intensity of the predominant waves, currents, orientation of navigation channel, basin breakwaters, seafloor morphology and sediment sources. Due to the geographic location of LNG port it lays within a sediment sink for sediments supplied from different alternating directions by several pathways, flowing towards the N-W, S-W, N-E, and S-E quadrants. Most of these currents components are substantially effective in transporting fine-grained sediment towards the navigation channel axis and contiguous basins. Together with these currents, the predominant NW and SE waves acting to agitate and stirrup sediments in the vicinity of the port, and thereby accelerating sedimentation rates.
\end{abstract}

Keywords: Sedimentation Rate, Nile Delta, Navigation Channel, Bed Load, Suspended Load and Sediment Transport

\section{Introduction}

During the last three decades, there have been a large number of harbors built along the Nile delta coast as a result of the increasing development of this valuable region. Unfortunately, most of these harbors are experiencing frequent sedimentation and siltation in their access channels due to the higher littoral drift rate and sedimentation imbalance [1]. Consequently, harbor authorities have to periodically dredge and remove away the accumulated sand in order to improve the navigation shoaling. For example at the Damietta harbor, routinely annual dredging of its channel has being undertaken since 1986, averaging of $1.18 \times 10^{6} \mathrm{~m}^{3} / \mathrm{yr}$ [2]. Studies dealt with sedimentation of the Damietta channel are also discussed by Deabes [3] and Abd-Allah, et al. [4].
The Liquefied Natural Gas (LNG) port was constructed in 2004, to export liquefied natural gas to other countries worldwide. The port is located on the inner continental shelf of the northwestern Nile Delta and at about 13-km southwest of the Rosetta Nile mouth. The turning and berthing basins (15 $\mathrm{m}$ depth) are connected to the deep water by means of dredged channel-entrance of $4 \mathrm{~km}$ length (Figure 1). This navigation channel is oriented in the NW direction ( 1350 from the north) and attaining about $15-\mathrm{m}$ depth and $245 \mathrm{~m}$ width. The berthing basin is connected with the shore facilities via a $\sim 2.0-\mathrm{km}$ long pier (pilled jetty). This long pier carries the liquefied gas pipeline system up to the berthing basin. The side slopes of the channel are approximately 1:25 (eastern bank) and 1:75 (western bank). The port basins are protected from the N-W waves by a breakwater of $\sim 900 \mathrm{~m}$ length which is roughly parallel to the shoreline. 


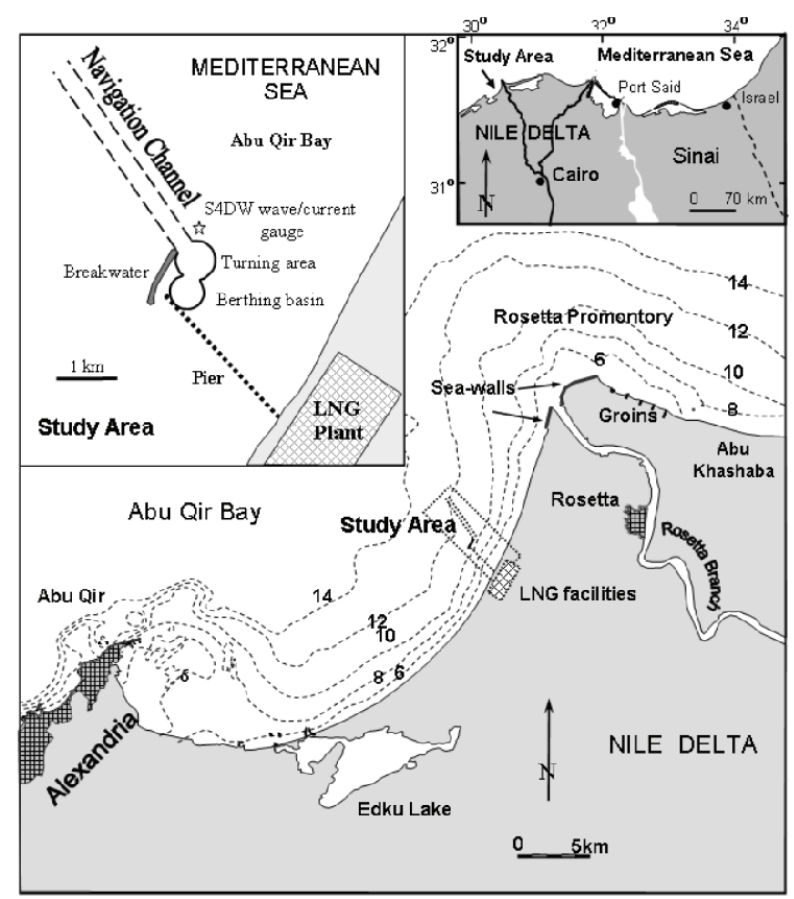

Figure 1. Map of Abu Qir Bay on the Nile delta coast showing location of the Natural Gas (LNG) Port. The inset map shows the navigation channel, the turning and berthing basins of the port. Depth contours in maters.

This breakwater is placed at $11.5 \mathrm{~m}$ depth contour. This breakwater also provided shelter for anchored vessels.

The primary objective of this study is to estimate the monthly sedimentation rates in the navigation channel of the LNG port using a developed numerical model. The second objective is to analyze driving forces (waves and currents) that are influenced in the sedimentation process. Generally, there are two approaches commonly used when estimating the sedimentation rates in channels and trenches. The first method involves calculating different change in water depth between two successive bathymetric surveys and the second empirically computes the volume of material that deposited into a navigation channel or a pathway. In this study a mathematical model has been developed to estimate rates of sediment deposited in the navigation channel.

\section{Material and Methods}

In this study, main factors contributing to the process of sedimentation of the LNG port are assessed, including waves, currents, bathymetry and grain size distribution of seabed sediments. Wave and current data are provided by the coastal Research Institute [5]. Whereas the nearshore bathymetry and mean grain size distribution of the nearshore area hosted the navigation channel and port basins are consulted from Frihy et al. [6].
Wave regime is statistically analyzed from wave records measured at Abu Qir Bay (see inset map in Figure 1 for location). Waves were measured using S4DW gauge installed in $10 \mathrm{~m}$ water depth immediately north of the turning area. This wave gauge records both directional wave and current spectrum for 20 minutes every 4 hours. Measurements were recorded over 12 months between October 2004 and September 2005. The raw data obtained from the S4DW gauge was transferred to a PC computer and statistically analyzed to determine wave height, wave period, wave direction and current (speed and direction).

\subsection{Mathematical Model Developed}

In preceding years, many simplest prediction methods have been proposed to calculate the sedimentation rate of dredged channels. More reliable prediction methods are those used mathematical or numerical model in which the sediment transport rate is computed from current and wave information. Basically, an accurate sedimentation prediction requires diverse information on detailed field survey to determine the boundary conditions, current speed, streamline patterns, wave characteristics, grain size, composition and porosity of bed materials, sediment concentration, particle fall velocities of suspended sediment and effective bed roughness.

Before discussing the mathematical approach developed in this study a cross and longitudinal diagram for the navigation channel with mathematic definition are presented in Figure 2. The present model is developed to

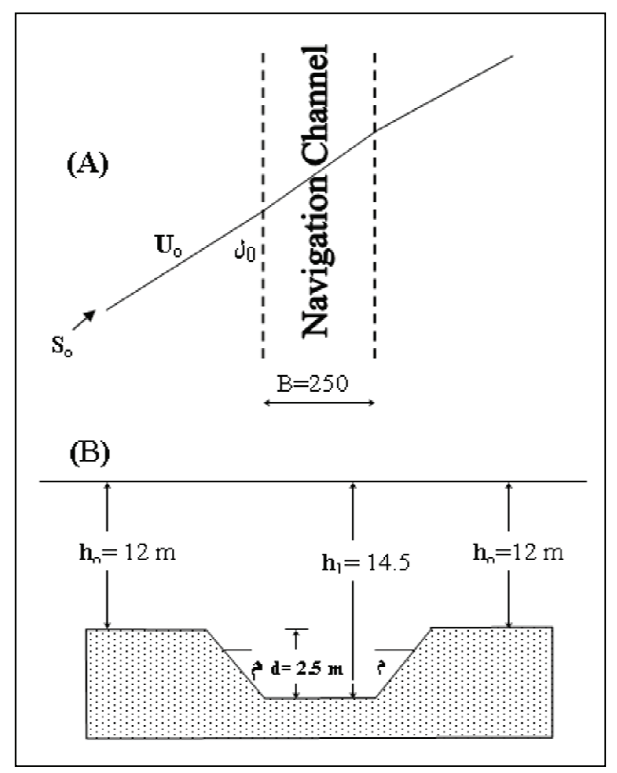

Figure 2. Longitudinal (A) and across-navigation channel sections (B) of LNG port, with mathematic definitions cited in the text. 
compute the sediment transport rate (bed-load and suspended-load) from the current and wave characteristics according to the transport law derived by Bailard [7] and Bailard and Inman [8], their formulae are given as follow:

$$
\begin{gathered}
q_{b}=\frac{\rho f_{w} e_{b}}{\left(\rho_{s}-\rho\right) g \tan \gamma}\left(U^{3}-\frac{\tan \beta}{\tan \gamma}|U|^{3}\right) \\
q_{s}=\frac{\rho f_{w} e_{s}}{\left(\rho_{s}-\rho\right) g W_{s}}\left(\left|U^{3}\right| U-\frac{e_{s}}{W_{s}} \tan \beta|U|^{5}\right)
\end{gathered}
$$

in which :

$q_{b}=$ instantaneous bed-load transport rate per unit length $\left(\mathrm{m}^{2} / \mathrm{sec}\right)$

$q_{s}=$ instantaneous suspended-load transport rate per unit length

$f_{w}=$ friction factor

$e_{b}=$ efficiency factor for bed load transport $(=0.11-0.15)$

$e_{s}=$ efficiency factor for suspended load transport $(=0.016-0.024)$

$\beta=$ local bottom slope

$\gamma=$ dynamic friction angle

$\gamma=0.75$ for $\Phi=0^{\circ}, \gamma=0.75$ for $\Phi=90^{\circ}$ and

$\gamma=1.1$ for $\Phi=180^{\circ}$ (liner interpolation for intermediate values)

$W_{s}=$ particle fall velocity $\quad(\mathrm{m} / \mathrm{sec})$

$U=\left|U^{2}{ }_{w}+U^{2}{ }_{c}+2 U_{w} U_{c} \cos \Phi\right|^{0.5} \quad(\mathrm{~m} / \mathrm{sec})$

$=$ instantaneous near-bed velocity vector

$U_{w}=\hat{u}_{\delta} \sin (\omega t)=$ near-bed orbital velocity $(\mathrm{m} / \mathrm{sec})$

$U_{c}=$ near-bed current velocity $\quad(\mathrm{m} / \mathrm{sec})$

$\Phi=$ angle between current direction and wave propagation direction

$\hat{u}_{\delta}=$ velocity at the edge of the wave boundary layer $=\omega \widehat{A}_{\delta}$

$\omega=2 \pi / \mathrm{T}=$ angular velocity

The friction factor $f_{w}$ is calculated as follows.

$$
f_{w}=\exp \left[-6+5.2\left(\hat{A}_{\delta} / K_{s}\right)^{-0.19}\right]
$$

in which:

$$
\hat{A}_{\delta}=\frac{H}{2 \sin h(k h)}
$$

$=$ the peak value of the orbital excursion

$H=$ wave height

$k=$ wave number

$h=$ water depth

$K_{s}=$ bed roughness

$K_{s}=2 d_{50}$

$d_{50}=$ is the diameter of grain size

The particle fall velocity is calculated as follows.

$$
W_{s}=\frac{10 v}{d}\left[\left(1+\frac{0.01(S-1) g d^{3}}{v^{2}}\right)^{0.5}-1\right]
$$

for $100<d<1000 \mu \mathrm{m}$

in which:

$$
\begin{aligned}
& d=d_{50}=\text { sieve diameter } \\
& S=\text { specific gravity }(=2.65) \\
& v=\text { kinematic viscosity coefficient } \quad\left(\mathrm{m}^{2} / \mathrm{sec}\right) \\
& v=1.011 \times 10^{-6} \mathrm{~m}^{2} / \mathrm{sec} \text { at } \mathrm{T}=20^{\circ} \mathrm{C} \\
& v=\left[1.14-0.031(\mathrm{~T}-15)+0.00068(\mathrm{~T}-15)^{2}\right] \times 10^{-6}
\end{aligned}
$$

The sedimentation rate per unit length of the navigation channel of LNG port is equal to sum of the bed-load transport which was completely deposited in the channel plus a small portion of suspended-load deposited in the channel $(\Delta S)$. According to Sutrench model [9], the sedimentation rate $(\Delta S)$ per unit length of channel resulting from the incoming suspended-load sediment transport can be calculated by the following equation:

$$
\Delta S=e S_{0} \sin \alpha_{0}
$$

in which:

$e=$ the trapping efficiency factor

$S_{0}=$ incoming suspended load transport

$\alpha_{0}=$ the approach angle (angle between the direction of current and channel axis)

The trapping efficiency factor $(e)$ is defined as the relative difference of the incoming suspended load transport and the minimum suspended load transport in the channel. In the present study the trapping efficiency factor $(e)$ for the navigation channel of the LNG port has been determined using the graphs constructed by the application of Sutrench model [9].

\section{Results and Discussion}

The first requirement in dealing with harbor sedimentation is to understand the processes and hydrodynamic forces dominated, such as waves, water circulation, sediment sources, seabed topography and port orientation.

\subsection{Wave Characteristics}

Waves and currents are the principal driving forces for the transport of sediments on the most of the coasts and adjacent shelves. The main function of waves is to agitate the sediments and put them in suspension case. They are also responsible for driving sediment along shoreline and/or in the on-offshore directions. So characterization of waves and currents is necessary to understand their role in inducing shoreline changes and sedimentation process in channels and waterways.

Results yielded from statistical analysis of wave data recorded at the LNG port are depicted as monthly and 
annual roses in Figures 3(A) and 3(B). As can be seen, waves mainly approach the port from two quadrants, the $\mathrm{N}-\mathrm{W}$ (NNW, NW, and WNW) and N-E (NNE, NE, and ENE). The percentage of occurrence of waves blown from the N-W and N-E quadrants, respectively, is $92 \%$ and $7 \%$ during the examined wave period. Winter storm-waves, $\mathrm{Hs}>2 \mathrm{~m}$, occurred 8 times versus ordinary waves (Hs less than $2 \mathrm{~m}$ ). About $81 \%$ of waves have wave height less than $1.0 \mathrm{~m}$. Maximum and average annual significant wave height are $4.51 \mathrm{~m}$ and $0.66 \mathrm{~m}$, respectively, (measured at 10-m water depth) with a mean peak spectral wave period of 6.7 second. Overall, the study area is wave dominated environment. Tide is a typical semi-diurnal microtidal regime with a mean tidal range of $50 \mathrm{~cm} \mathrm{[3].}$

The monthly distribution of wave direction in Figure 3(A) demonstrates that the N-W waves appear in all examined one-year period, while the N-E waves exist only in 5 months (October, November, December, January and April). Only three months (October, December, and May) reveal waves blowing from the S-W quadrant. As expected, the monthly average and maximum wave height in winter period is greater than that in summer

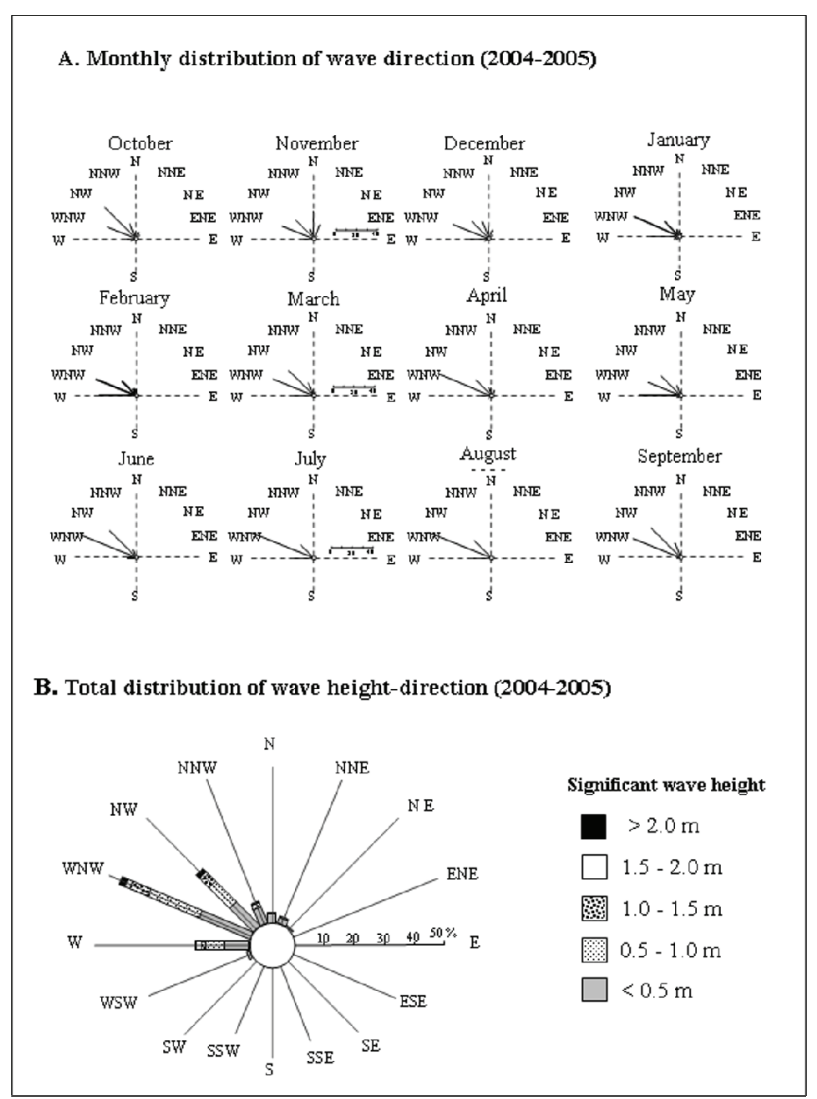

Figure 3. (A) Monthly distribution of waves measured at Abu Qir Bay between October 2004 and September 2005 (12 months). (B) Total distribution of wave height-direction (wave rose) at the same period. period. Among all directions, the N-W and to some extent the N-E waves are of greater importance for sediment transport processes because of their long duration, particularly in winter. These predominant wave components are responsible for driving energy toward the LNG navigation channel resulting in agitation and turbulence of the seabed sediment. The offshore breakwater east of the turning and berthing basins provide natural protection and sheltering from waves arrives from the NW (92\%), and totally exposed to the NE component (7\%), Figures 1 and 3. Therefore, the lack of any significant shelters of the navigation channel means that it is essentially open to all waves approaching from the prevailing N-W and N-E quadrants, leading to stirrup and agitates sediments in the vicinity of the port, and thereby increasing sedimentation.

\subsection{Current Regime}

Current regime was analyzed from records measured immediately east of LNG port using the S4DW wave gauge (see position in Figure 1). Results demonstrate that currents in the study area moving towards all directions, being N-W (52\%), S-W (20\%), N-E (15\%) and $\mathrm{S}-\mathrm{E}(13 \%)$ quadrants (Figures 4 and 5). As the monthly average $(9.6 \mathrm{~m} / \mathrm{sec})$ and maximum current speeds $(32.5 \mathrm{~m} / \mathrm{sec})$ in winter are greater than that in summer months $(3.2 \mathrm{~m} / \mathrm{sec}$ and $15.3 \mathrm{~m} / \mathrm{sec})$, sedimentation rate in winter is much higher (Figure $\mathbf{6}(\mathbf{C})$ ). Currents flowing towards the NE to SW $(20 \%)$ that are responsible for transporting sediment from moving sediment eroded from the Rosetta promontory are essentially effective in the sedimentation process of the navigation channel and the berthing basin. The Rosetta promontory north of the study area has been subjected to some of the most severe shoreline and seabed erosion of all the world's delta coastlines during the 20th century $[6,10]$, see Figure 1 for location. Under the effect of waves and currents major transport reversal occurs in front of the Rosetta mouth, creating a divergent sediment transport nodal zone where sand moves to both the east and southwest away from the month. Acting with the S-W currents $(20 \%)$ are the opposing N-E currents (15\%) that move sediment from Abu Qir Bay towards the navigation channel as well as the port basins (Figure 5). Both the southwest and northeast-directed sediment are the major factors contributed to the sedimentation processes of the LNG port. The other opposing seaward N-W (52\%) and landward S-E (13\%) currents also affect the port substantially. However, among these two quadrants, the NW (17\%) and SE $(3.6 \%)$ current components have insignificant contribution to the sedimentation processes because they are generally flowing parallel to the main axis of the entrance channel. It has been found that the interpreted current regime in LNG area is closely corresponds to the overall pattern obtained by Frihy et al. [6] based on the 


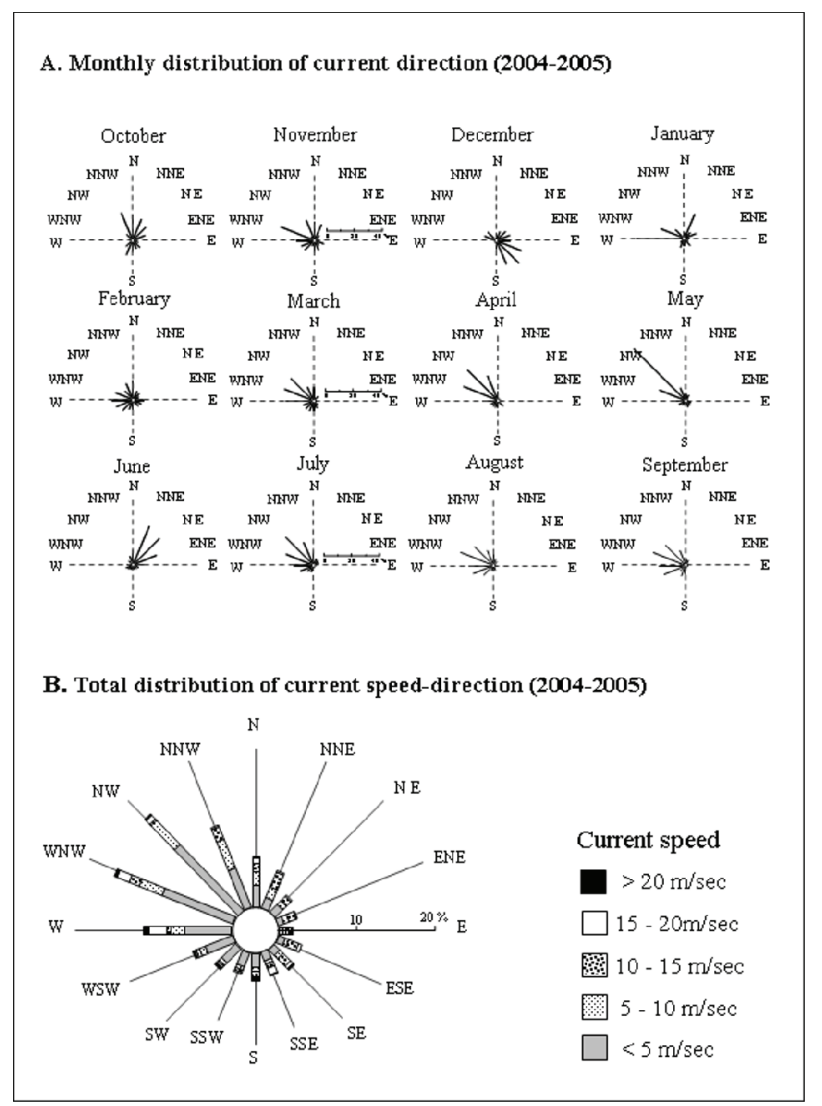

Figure 4. (A) Monthly distribution of current directions at Abu Qir Bay between October 2004 and September 2005 (12 months). (B) Total distribution of current speed direction (current rose) at the same period.

spatial dispersion of mean grain size and magnetic minerals in the seabed sediments.

\subsection{Sedimentation Process}

Grain size distribution of sediments hosting LNG port has been described by Frihy et al. [6]. Accordingly, cross-shelf sediment pattern shows fining trends in two directions. A seaward fining trend starts from the shoreline to a distance of $10 \mathrm{~km}$ at $15 \mathrm{~m}$ water depth $(\mathrm{Mz}=$ 0.004-0.063-mm). This fining pattern indicates sediment transport to the NW and is mainly caused by a shoreward increase of wave energy dissipation induced by shoaling and current-driven sediment transport processes. Unlike this pattern, cross-contour clay and silt belts $(0.01$ to $0.06 \mathrm{~mm})$ truncate the sand belts at the north sector of the area. This sediment pattern suggests that the fine-grained sand and mud flooring the vicinity of the port area are able to be bypassed to the navigation channel and basins and thereby inducing sedimentation.

The data required to run the developed include time series of waves and currents, grain size of seabed sediment
$(\mathrm{Mz}=0.09)$, channel width $(250 \mathrm{~m})$, length $(4000 \mathrm{~m})$, orientation of channel axis ( $135^{\circ}$ from north) and bathymetric map of (see Figure 5). Results obtained from running the developed numerical model are listed in Table 1. As can be noticed the sedimentation rate calculated during winter (October 2004-March 2005) is greater than that of summer (April 2005-September 2005). Winter period is generally characterized by higher monthly sedimentation rates $\left(>0.1 \times 10^{6} \mathrm{~m}^{3} /\right.$ month $)$, with a maximum rate of $0.388 \times 10^{6} \mathrm{~m}^{3} /$ month occurred in January 2005 . Whereas, lower rates $\left(<0.1 \times 10^{6} \mathrm{~m}^{3} / \mathrm{month}\right)$ occurred in summer, with a lowest value $0.048 \times 10^{6} \mathrm{~m}^{3} /$ month in July 2005 . The annual rate of sedimentation is $1.977 \times$ $10^{6} \mathrm{~m}^{3} / \mathrm{yr}$.

The proportion of bed-load sediments fluctuates between 68.2 and $83.9 \%$, with an average of $78 \%$. Suspended-load varies from 16.1 to $31.8 \%$, with an average $22 \%$. This means that suspended-load sediments contributed to about $22 \%$ of the volume of deposited sands, while bed-load sediments represent about $78 \%$ of that volume.

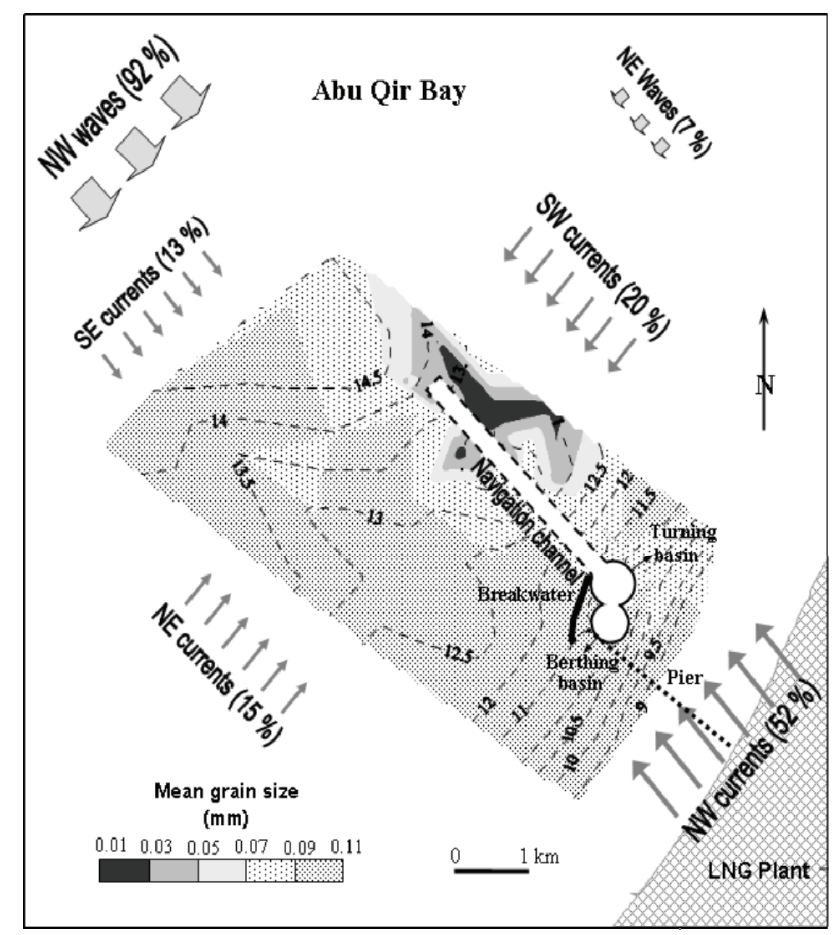

Figure 5. Map of the nearshore area of the study LNG port showing spatial distribution of mean grain size of bottom sediments and bathymetry (modified from Frihy et al. [6]). Sediment transport paths involved in the sedimentation processes of the port channel and basins are depicted as arrows. The size of arrows quantitatively represents wave and current proportions. The general transport paths indicate that the port area is interpreted as a sediment sink for several current pathways towards the $N-W, S-W, N-E$, and S-E quadrants. Depth contours in meters. 


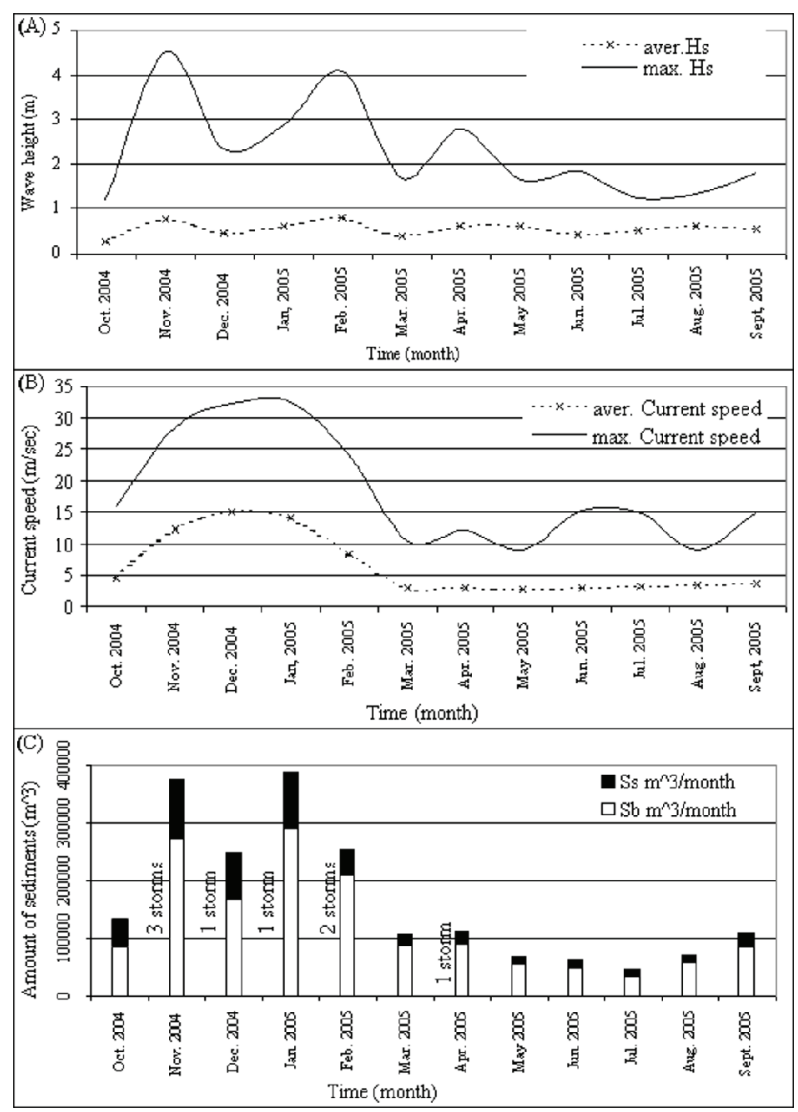

Figure 6. Monthly average and maximum values of significant wave height (A) and current speed (B). (C) Sediments involved in the processes of sedimentation of the navigation cannel and port basins are suspended matters (Ss) and bedload modes (Sb). Results estimated using the model developed in the present study between October 2004 and September 2005.

Table 1. Calculated monthly volume, suspended and bed load sediments acting in the navigation channel of LNG port between october 2004 and september 2005.

\begin{tabular}{cccccc}
\hline Months & $\mathrm{Sb}\left(\mathrm{m}^{3}\right)$ & $\mathrm{Ss}\left(\mathrm{m}^{3}\right)$ & total Qs $\left(\mathrm{m}^{3}\right)$ & $\mathrm{Sb} \%$ & $\mathrm{Ss} \%$ \\
\hline Oct. 2004 & 91702.58 & 33745.54 & 125448.12 & 73.10 & 26.9 \\
Nov. 2004 & 274124.91 & 103036.86 & 377161.77 & 72.68 & 27.32 \\
Dec. 2004 & 169666.30 & 79275.65 & 248941.95 & 68.15 & 31.85 \\
Jan. 2005 & 290910.17 & 97072.49 & 387982.66 & 74.98 & 25.02 \\
Feb. 2005 & 209939.43 & 44601.09 & 254540.52 & 82.48 & 17.52 \\
Mar. 2005 & 89237.03 & 17067.55 & 106304.58 & 83.94 & 16.06 \\
Apr. 2005 & 91493.67 & 20765.84 & 112259.51 & 81.50 & 18.50 \\
May 2005 & 56443.38 & 13660.22 & 70103.60 & 80.51 & 19.49 \\
Jun. 2005 & 49917.33 & 13782.31 & 63699.64 & 78.36 & 21.64 \\
Jul. 2005 & 35261.74 & 12871.43 & 48133.16 & 73.26 & 26.74 \\
Aug. 2005 & 60384.48 & 12040.26 & 72424.74 & 83.38 & 16.62 \\
Sept. 2005 & 85948.23 & 24332.42 & 110280.65 & 77.94 & 22.06 \\
Total period & 1505029.24 & 472251.66 & 1977280.9 & 77.60 & 22.40 \\
\hline
\end{tabular}

( $\mathrm{Sb}=$ bed-load sedimentation rate

Ss $=$ suspended-load sedimentation rate)

\section{Summary and Conclusions}

The two port basins (turning and berthing areas) and the contiguous navigation channel of LNG port are located at Abu Qir Bay on the northwest margin of the Nile delta. This port is of considerable socioeconomic importance, supporting exporting gas industry that relies on the sheltered port areas to serve as mooring points for the international gas tankers. Presently, the channel entrance and the two basins (15-m water depth) are experiencing considerable sedimentation; therefore they are dredged periodically to insure safety navigation for $\mathrm{LNG}$ vessels.

A dataset of waves, current and texture of seabed are interpreted to precisely evaluate sedimentation processes taking place in this port. Waves approach the port blowing from two main dominant quadrants, the $\mathrm{N}-\mathrm{W}$ and N-E. These waves actively act to agitate and stirrup sediments as bead-load and suspended modes, directly toward the navigation channel and port basins. However, the port basins are protected from wave exposure from the N-W waves by a $900-\mathrm{m}$ breakwater and not from the $\mathrm{N}-\mathrm{E}$ waves.

Wind and wave-driven currents are responsible to accumulate large portion of sediments (very fine sand and mud) in the port vicinity and subsequently negatively affecting the navigation channel and basins. Both the opposing S-W and N-E current paths produce sand and mud accumulation in the nearshore area hosting the port channel and basins. The principal sources of sediment contributed to the processes of sedimentation of the LNG are the eroded Rosetta promontory and the inner shelf of Abu Qir Bay. These sediment sources supply large quantities of fine-grained sand and mud to the basins and channel via opposing S-W and N-E currents. Other opposing N-W (seaward) and S-E (landward) currents have also significance effect, with exception of the NW and SE components which are flowing parallel to the channel axis. The seaward current moves sediment from the surfzone whereas landward one from offshore sources, both toward the port. This generally implies that the navigation channel and its adjacent basins are apparently acting effectively as a sediment sink for sediments supplied from the four quadrants.

The dataset interpreted in this study are also incorporated into a mathematical procedure for calculating rate of sedimentation in the port facilities. Monthly sedimentation rates yielded from applying the developed model fluctuate between $0.048 \times 106$ and $0.388 \times 106 \mathrm{~m}^{3} /$ month, with an annual rate of $1.977 \times 106 \mathrm{~m}^{3} / \mathrm{yr}$. This annual rate is closely comparable to the sediments accumulated in the port as estimated by HR Wallingford (2004) based on bathymetric survey and numerical model. Suspended-load sediment contributed to about one-fifth of the total of sediments, while the bed-load mode is ap- 
proximately four-fifth of the sediments that deposited in the navigation channel. In comparison, these estimated proportions are found to be in agreement with results obtained by Komar and Inman [11], Komar [12] and Inman, et al. [13].

\section{Acknowledgements}

The author appreciates the assistance of the staff of the Coastal Research Institute for the field and laboratory activities of this study. Appreciation is also given to Drs. Omran Frihy, Abdel Monaam Badr and Abu Bakr.

\section{References}

[1] O. E. Frihy and D. Lawrence, "Evaluation of the Modern Nile Delta Promontories: Development of Accretional Features during Shoreline Retreat," Environmental Geology, Vol. 46, No. 6, 2004, pp. 914-931.

[2] O. E. Frihy, A. M. Badr and M. S. Hassan, "Sedimentation Processes at the Navigation Channel of the Damietta Harbour on the Northeastern Nile Delta Coast of Egypt," Journal of Coastal Research, Vol. 18, No. 3, 2002, pp. 459-469.

[3] E. A. M. Deabes, "The Study of Sea Level Changes and Current at Rosetta and Damietta Outlets and Abu Qir Bay," M. Sc. thesis, Faculty of science, University of Alexandria, 2002.

[4] M. A. Abd-Allah, A. H. El-Gindy and E. A. M. Deabes, "Estimation of Sedimentation Rates in the Navigation Channel of Damietta Harbour, Egypt," Journal of Arab Academy for Science, technology and Marine Transport, Vol. 30, No. 59, 2005, pp. 54-61.
[5] CoRI, "Sea Waves and Currents Characteristics at West Side of Loading ARMS, ELNG Port-Idku Site," Technical Reports, Coastal Research Institute, 2004-2006.

[6] O. E. Frihy, M. S. Hassan, E. A. Deabes and A. M. Badr, "Seasonal Wave Changes and the Morphodynamic Response of the Beach-Inner Shelf of Abu Qir Bay, Mediterranean Coast, Egypt," Marine Geology, Vol. 247, No. 3-4, 2008, pp. 145-158.

[7] J. A. Bailard, "Total Load Sediment Transport Model for Plane Sloping Beach," Journal of Geophysical research, Vol. 86, No. C11, 1981, pp. 10938-10954.

[8] J. A. Bailard and D. L. Inman, "An Energetics Bed Load Model for Plane Sloping Beach," Journal of Geophysical research, Vol. 86, No. C3, 1981, pp. 2035-2043.

[9] L. C. Van Rijn, "Sedimentation of Dredged Channels and Trenches," In: Herbich, J. B., Ed., Handbook of Coastal Ocean Engineering, Gulf Pub., Co., Houston, TX, 1991, pp. 609-650.

[10] M. A. El Sayed, N. A. Younan, A. M. Fanos and K. H. Baghdady, "Accretion and Erosion Patterns along Rosetta Promontory, Nile Delta coast," Journal of Coastal Research, Vol. 21, No. 3, 2005, pp. 412-420.

[11] P. D. Komar and D. L. Inman, "Longshore Sand Transport on Beaches," Journal of Geophysical Research, Vol. 75, No. 30, 1969, pp. 5514-5527.

[12] P. D. Komar, "The Relative Significance of Suspension Versus Bed-Load on Beaches," Journal of Sedimentary petrology, Vol. 48, 1978, pp. 921-932.

[13] D. L. Inman, J. A. Zampol, T. E. White, D. M. Hanes, B. W. Waldorf and K. A. Kastens, "Field Measurement of Sand Motion in the Surf Zone," Proceedings of 17th International Conference on Coastal Engineeering, ASCE, New York, 1980, pp. 1215-1234. 